\title{
Two new species of Engertia Dalla Torre, 1913 and Philacelota Heller, 1900 from Indonesia and the Philippines with a revised identification key (Coleoptera: Scarabaeidae: Melolonthinae)
}

\author{
Artem M. PROKOFIEV \\ A.N. Severtsov Institute of Ecology and Evolution, Russian Academy of Sciences, \\ Leninskii prospect 33, Moscow, 119071 Russia. \\ Email: prokartster@gmail.com \\ urn:1sid:zoobank.org:author:C194844F-183F-44ED-AAE8-E33482CAD155
}

\begin{abstract}
Two new species of the leucopholine genera Engertia Dalla Torre, 1913 and Philacelota Heller, 1900 are described. Engertia allolepis sp. nov. from Ambon Island in the Moluccas, Indonesia, can be distinguished from the other species of the genus by the heterogeneous setosity on the elytra as well as by a very robust and arcuate aedeagus. Philacelota leucothea sp. nov. from Luzon Island, Philippines, differs from the other species of Philacelota in the scaled whitish vestiture of the pronotum and elytra, as well as in the unidentate protibiae and in the shape of parameres. The length of the $3^{\text {rd }}$ antennomere is the only reliable character for the separation of the genera Engertia and Philacelota. A revised dichotomous key for identification of males and females of all species of Engertia and Philacelota is given. The genus Philacelota is reported from the Philippines for the first time.
\end{abstract}

Keywords. Scarab beetles, Engertia allolepis, Philacelota leucothea, determination key, Indo-Australian Archipelago.

Prokofiev A.M. 2019. Two new species of Engertia Dalla Torre, 1913 and Philacelota Heller, 1900 from Indonesia and the Philippines with a revised identification key (Coleoptera: Scarabaeidae: Melolonthinae). European Journal of Taxonomy 561: 1-13. https://doi.org/10.5852/ejt.2019.561

\section{Introduction}

The genus Engertia Dalla Torre, 1913 (Phila Brenske, 1897, preoccupied name) includes moderately sized to small chafers characterized by the presence of an antennal club with five or six lamellae in the males and four or five lamellae in the females (Brenske 1897; Keith 2006). Six species have previously been described from Sri Lanka, the Philippines and eastern Indonesia to Papua New Guinea (Brenske 1897; Moser 1913; Keith 2006; Prokofiev 2016a). A historical overview and analysis of the systematic position of Engertia were provided by Keith (2006), and some additional data on the morphology and distribution were reported by Prokofiev $(2015,2016 b)$.

The genus Philacelota Heller, 1900 was proposed for two species inhabiting northern Sulawesi and Sula Mangoli, Indonesia (Heller 1900). A third species from Flores Island was recently described by Zidek (2018). Members of Philacelota are very similar to those of Engertia in overall size, shape and vittate 
elytra, and in the general shape of the aedeagi, but differ in the presence of seven lamellae in the male antennal club and in the long $3^{\text {rd }}$ antennomere in both sexes (vs short in the members of Engertia).

The present contribution is devoted to the description of two new species of Engertia and Philacelota from the islands of Ambon and Luzon, respectively. The latter record considerably extends the known distribution range of the genus Philacelota.

\section{Material and methods}

All the measurements of the entire specimens are based on the combined length of the head, pronotum and elytra measured individually. Both the dorsal and ventral surfaces of the beetles are covered with modified (thin, flat, expanded to different degrees) setae here referred to as 'scales'. Sometimes, the specimens appear to be more or less worn, with their scales lost to varying extents. However, the scaled areas can easily be distinguished from the glabrous ones by the presence of punctures, which are always setigerous in Engertia spp. The label data are cited verbatim. Separate labels are separated by '/'. The following collections were studied (their curators are listed in parentheses):

cAP $=$ the author's working collection, Moscow, Russia

MNHN = Muséum national d'Histoire naturelle, Paris, France (O. Montreuil, A. Mantilleri)

NHM = Natural History Museum, London, United Kingdom (M. Barclay, M. Geiser)

$\mathrm{ZMB}=$ Museum für Naturkunde der Leibniz Gemeinschaft, Berlin, Germany (J. Frisch, J. Willers)

\section{Comparative material examined}

Engertia amboinae (Brenske, 1897): INDONESIA • 1 ô, 2 우: "Molucc. Ambon / Ex Musaeo Van

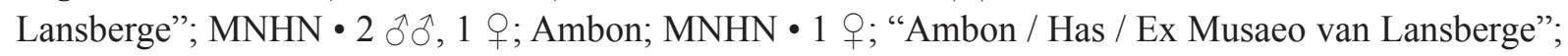
MNHN • 2 + 9 ; Ambon; NHM • 1 क; W. Irian, Yapen I., northern coast, Yapen Barat, Rosbori vill.; 14 Nov. 2012; A.M. Prokofiev leg.; cAP; 1 isolated elytron; W. Irian, Miosidi islet between Biak \& Yapen Is., sea coast; 15 Nov. 2012; A.M. Prokofiev leg.; cAP.

Engertia germanica Prokofiev, 2016: NEW GUINEA • 2 $\widehat{\jmath}$ (holotype and paratype); D.N. Guinea, Berlinhafen; H. Schoede S.G.; ZMB • 1 ふै; "Nouv.-Guinee Duivenbode”; MNHN.

Engertia papuana (Moser, 1913): NEW GUINEA • 1 今̊; "Depapre area/Cyclops mts., Sentani”; 02³134' S, 140³1' E; 19-31 Feb. 2009; Zamesov, Sinyaev and Romanenko leg.; cAP.

Engertia setifera (Moser, 1913): INDONESIA • 1 § ; "Has / Ambon / Ex Musaeo van Lansberge"; MNHN • 1 đ̊; Seram I., Elpa Putih, 40 km N of Sahulau vill., Waipia distr., on light; 17-20 Nov. 2011; A.M. Prokofiev leg.; cAP.

Philacelota submaculata Heller, 1900: INDONESIA •1 Ò; “Celebes / Kema / Ex Musaeo van Lansberge”; MNHN• 3 우; “W. Celebes G. Tompoe Paloe J.P. Ch. Kalis 2700””; 1937; MNHN.

A drawer containing Brenske's and Moser's types of Engertia in ZMB (type specimens of E. maculosa (Brenske, 1896), E. papuana and E. setifera according to the data provided in the museum catalogue) has not been available since 2014 when I requested these types for study (J. Willers, personal communications, 2014-2016). Thus, these type specimens were not included in the present study and their whereabouts is unclear at present. The data for E. lii Keith, 2006, E. maculosa and for females of E. setifera were taken from Brenske (1896), Moser (1913) and Keith (2006). The data for P. jakli Zidek, 2018 and P. sulana Heller, 1900 were taken from Heller (1900) and Zidek (2018). 


\title{
Results
}

\author{
Class Insecta Linnaeus, 1758 \\ Order Coleoptera Linnaeus, 1758 \\ Family Scarabaeidae Latreille, 1802 \\ Subfamily Melolonthinae Samouelle, 1819 \\ Genus Engertia Dalla Torre, 1913 \\ Engertia allolepis sp. nov. \\ urn:lsid:zoobank.org:act:3E17E5EE-4309-4836-9A06-4AB5994E3F32
}

Figs $1,2 \mathrm{~A}-\mathrm{G}$

\section{Diagnosis}

Engertia, with five lamellae in antennal club of males. Disc of pronotum with irregular callose areas. Elytra with glabrous costae and scale pattern forming longitudinal bands on interstices; scales on elytra lanceolate in $1^{\text {st }}$ to $3^{\text {rd }}$ interstices, but intermixed with setiform scales on $4^{\text {th }}$ and $5^{\text {th }}$ interstices and along apical margin of elytra. Propygidium with dense long setae; pygidium fully scaled. Abdominal ventrites 2 to 4 with isolated round patches of scales along midline. Aedeagus strongly arcuate, robust.

\section{Etymology}

The species epithet is based on the Greek words 'allos', meaning 'different', and 'lepis', meaning 'scale', due to the heterogeneous scales covering the elytra.

\section{Type material}

\section{Holotype}

INDONESIA • ○; " "Molucc. Ambon / Has / Ex Musaeo van Lansberge”; MNHN.

\section{Description (holotype)}

\section{Male}

Body (Fig. 1). Length $18.5 \mathrm{~mm}$, greatest width $7.5 \mathrm{~mm}$. Integument dark reddish-brown; vertex, pronotum and tarsal claws more infuscated; scales and pilosity yellowish to whitish.

HEAD. Clypeus pentagonal, with anterior margin weakly bisinuate in frontal view, slightly produced in middle and conspicuously reflexed; surface rugo-punctate; punctures moderately deep, bearing narrowly lanceolate to spiniform scales becoming much shorter and thinner along midline in posterior half of clypeus. Fronto-clypeal suture conspicuous, weakly concave. Frons rugo-punctate; punctures much denser along inner margins of eyes, bearing lanceolate scales replaced by moderately long erect setae on lateral thirds of anterior half-length of frons; vertex glabrous. Antennae consist of ten antennomeres, with five antennomeres in club (Fig. 2A); all antennomeres of club of equal length; $5^{\text {th }}$ antennomere half as long as $4^{\text {th }}, 3^{\text {rd }}$ and $4^{\text {th }}$ antennomeres of equal length; antennomeres of club strongly shagreened, antennomeres of funicle glabrous. Last maxillary palpomere elongate fusiform, with narrow, but deep impression on its outer side. Labrum weakly bilobed, covered by moderately long setae intermixed at sides with narrowly lanceolate scales; mentum deeply concave, bearing long setae along its lateral and posterior margins.

THORAX AND ABDOMEN. Pronotum narrower at base than base of elytra, 1.5 times as broad as long, broadest just before middle, strongly and almost equally convergent anteriad and posteriad; sides straight anteriad, weakly concave posteriad; anterior and posterior angles obtuse; anterior margin bisinuate; posterior margin strongly convex before scutellar shield; all sides of pronotum unbeaded. Pronotum roughly, but 
not deeply and very unevenly punctured, punctures slightly rugose with interspaces between punctures on disc somewhat callose; glabrous and callose medial longitudinal stripe present; scales on pronotum mostly lanceolate, but intermixed on disc with few setiform scales; moderately long setae present along anterior margin and near anterior angles of pronotum only. Propleura setose, with dense patch of lanceolate scales in their anterior halves. Scutellar shield broadly rounded apically, only punctured along lateral sides; punctures bearing narrowly lanceolate scales. Elytra with five conspicuous glabrous costae; base of elytron somewhat swollen; humeral and apical umbones rather weakly expressed. Interstices shallowly, but densely punctured; punctures of $1^{\text {st }}$ to $3^{\text {rd }}$ interstices bearing lanceolate scales, partially replaced by setiform scales in $4^{\text {th }}$ and $5^{\text {th }}$ interstices and along apical margin of elytra (Fig. 2B-C). Propygidium finely and densely punctured; punctures setigerous, bearing long setae; distal margin of propygidium with few isolated lanceolate scales (Fig. 2C). Pygidium densely covered by lanceolate scales (Fig. 2D), setose along lateral and apical margins. Prosternum, mesoventrite and metaventrite densely and finely rugo-punctate, densely covered with long setae; disc of metaventrite, metepimeron and metepisternum bearing some scales. First abdominal ventrite flat in middle; $1^{\text {st }}$ and $2^{\text {nd }}$ ventrites setose, remaining ventrites with isolated setae in their lateral thirds only, except last visible ventrite bearing rather dense setae of moderate length along its distal margin; all abdominal ventrites covered by ovate (lanceolate in uppermost parts) scales, more densely aggregated in uppermost reaches of each ventrite, forming small round patches of scales on $2^{\text {nd }}$ to $4^{\text {th }}$ ventrites along midline of abdomen (Fig. 2E); sutures between $2^{\text {nd }}$ and $5^{\text {th }}$ abdominal ventrites obliterated in middle.

Legs. Protibiae unidentate, with spur short and thick; middle and hind tibiae gracile; apex of hind tibiae with 12 separated bristles. Femora setose; lanceolate scales present on hind femora only; tibiae with sparse narrow scales and spiniform setae; tarsi with setae only. Tarsomeres 1-4 shortened, especially of fore tarsi; $1^{\text {st }}$ tarsomere of hind tarsi equal to $2^{\text {nd }}$ in length. Claws bifurcate, with lower lobe situated slightly closer to base of claw, parallel to upper one, distinctly shorter, but as broad as the latter.

Genitalia. Aedeagus (Fig. 2E, G) strongly arcuate, robust; phallobase remarkably deepened distally; parameres considerably narrowed toward apex, their ventral contour very weakly arcuate and dorsal contour almost straight; apical extensions of parameres small, oval, not upturned.

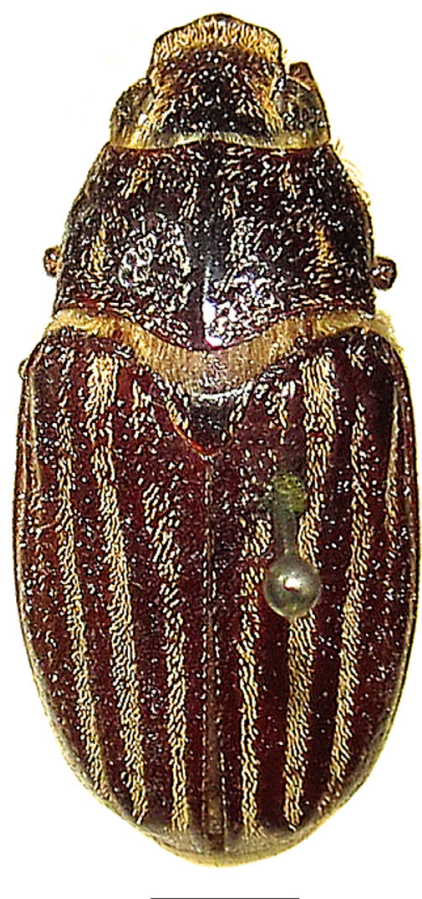

Fig. 1. Engertia allolepis sp. nov., habitus, holotype, $\widehat{\jmath}(\mathrm{MNHN})$. Scale bar $=2.5 \mathrm{~mm}$. 

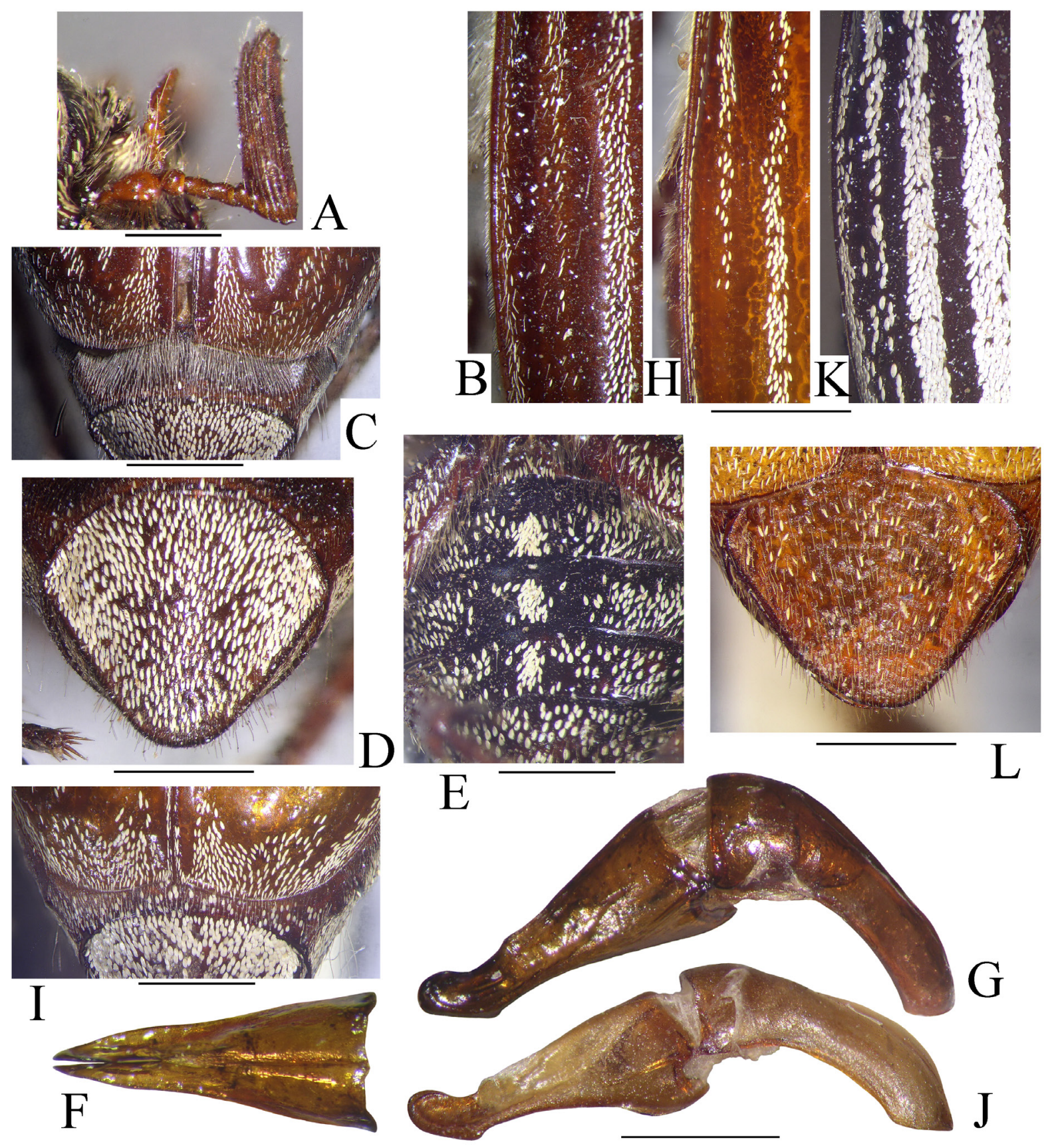

Fig. 2. A-G. Engertia allolepis sp. nov., holotype, $\widehat{\partial}(\mathrm{MNHN})$. A. Antenna. B. Lateral part of the elytron. C. Apical margin of elytra and propygidium. D. Pygidium. E. Abdominal ventrites 2-4. F. Parameres, dorsal view. G. Aedeagus, lateral view. - H-J. E. papuana (Moser, 1913), ठ̂, from Sentani (cAP). H. Lateral part of elytron. I. Apical margin of elytra and propygidium. J. Aedeagus, lateral view. K. E. amboinae (Brenske, 1897), ô, from Ambon (MNHN), lateral part of elytron. - L. E. setifera (Moser, 1913), Ô, from Seram, pygidium (cAP). Scale bars are in common for B, H and K, and for F-G and J. Scale bars: A-B, H, K = $1.5 \mathrm{~mm}, \mathrm{C}-\mathrm{G}, \mathrm{I}-\mathrm{J}, \mathrm{L}=2.5 \mathrm{~mm}$. 
Female

Unknown.

\section{Differential diagnosis}

Engertia allolepis sp. nov. is unique within the genus in the possession of both lanceolate and setiform scales in the outer elytral interstices (vs elytral scales more or less homogeneous in shape in all interstices in the other Engertia spp.; see Fig. 2H for representation). In other respects this new species is most similar to E. papuana (Moser, 1913), but differs from the latter in the much longer and denser pilosity of the propygidium (compare Fig. 2C and 2I) and in the somewhat callose disc of the pronotum. The aedeagi of E. allolepis sp. nov., E. amboinae (Brenske, 1897), E. germanica Prokofiev, 2016, E. papuana and E. setifera (Moser, 1913) are very similar to each other, but the aedeagus of E. allolepis sp. nov. is more arched in lateral view than that of the aforementioned species except $E$. germanica, and it can be further distinguished from the aedeagi of all the other species mentioned above in the deeper and broader apical portion of the phallobase and in the more robust and massive parameres (compare Fig. $2 \mathrm{G}$ with $2 \mathrm{~J}$ as an example).

Engertia allolepis sp. nov. is known from Ambon Island, where two other members of the genus are distributed: E. amboinae and E. setifera. Besides the heterogeneous vestiture of the elytra and the more robust aedeagus, the new species can be distinguished from $E$. amboinae by the scales in the elytral interstices being much narrower (lanceolate to setiform vs ovoid: Fig. $2 \mathrm{~K}$ ), scales along midline of the abdominal ventrites aggregated into spots (vs not aggregated), propygidium with long (vs short) setae, and from E. setifera by the pygidium being densely covered with scales (vs mainly setose: Fig. 2L), scales along midline of the abdominal ventrites aggregated into spots (vs not aggregated), and scales present on labrum and metaventrite (vs absent).

Genus Philacelota Heller, 1900

Philacelota leucothea sp. nov. urn:1sid:zoobank.org:act:BF182F51-5D7C-4F3E-937D-ED8458AADF21

Figs $3-4,5 \mathrm{~A}-\mathrm{B}$

\section{Diagnosis}

Philacelota with squamose vestiture. Disc of pronotum with narrow, longitudinal callose stripe. Elytra evenly scaled in males, while in females the scaled areas are intermixed with glabrous ones to form a variegated pattern. Propygidium of males with short acicular setae and sparse long setae, of females with short setae only; pygidium fully scaled in males, but with glabrous medial longitudinal stripe in females. Scales along midline of abdominal ventrites 2 to 4 evenly distributed. Aedeagus of characteristic shape.

\section{Etymology}

The name of this new species reflects the white scale covering of the beetles. Leucothea ('white goddess') is a poetic epithet of a Greek goddess. The species epithet is treated as a noun in apposition.

\section{Type material}

Holotype

PHILIPPINES • đ̊; "N O Luzon / Philippines Ch. Semper”; MNHN.

\section{Paratypes}

PHILIPPINES • 1 ภ, 2 우; same collection data as for holotype; MNHN. 
Description (holotype)

Male

Body (Fig. 3A). Length $15.0 \mathrm{~mm}$, greatest width $6.5 \mathrm{~mm}$. Integument reddish-brown; scales and pilosity whitish.

HEAD. Clypeus nearly crescent-shaped, with anterior margin arcuate in frontal view and weakly reflexed; surface roughly rugo-punctate, with long spiniform (slightly broadened at base, pointed at tip) scales. Fronto-clypeal suture conspicuous, almost straight. Frons and vertex roughly rugo-punctate; punctures denser on anterior half of frons; posterior half of frons and vertex with a narrow longitudinal callosity along midlength. Frons and vertex covered by elongate spiniform scales, denser toward inner margins of eyes, intermixed with sparse, moderately long setae. Antennae consist of 10 antennomeres, with seven antennomeres in club (Fig. 4A); all antennomeres of club of equal length; $3^{\text {rd }}$ antennomere with a strong anteromedial process; antennomeres of club strongly shagreened, antennomeres of funicle glabrous. Last maxillary palpomere elongately fusiform, with outer side impressed. Labrum weakly bilobed, covered by spiniform scales and sparse long setae; mentum deeply concave, bearing long setae along its lateral and posterior margins.
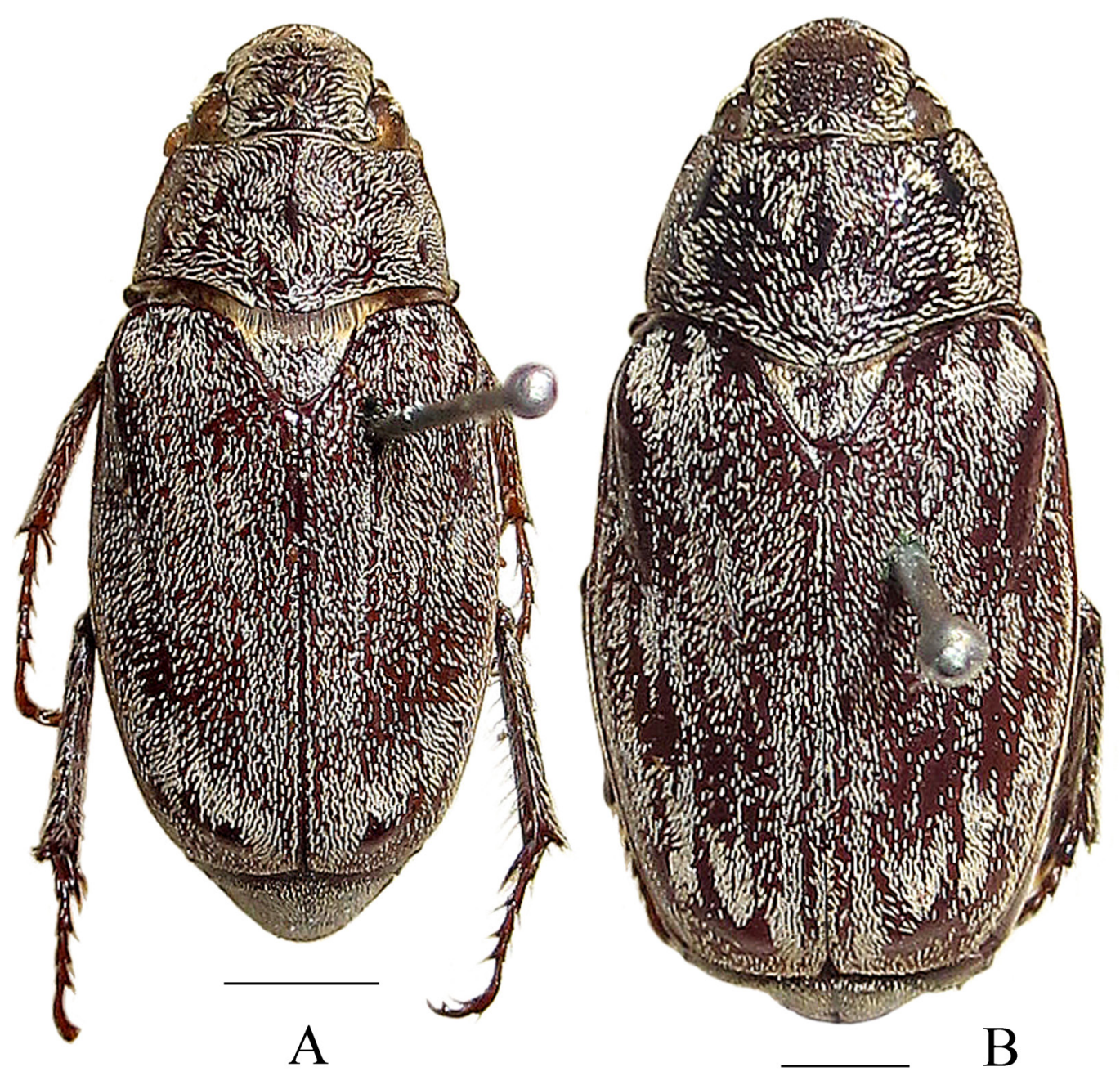

Fig. 3. Philacelota leucothea sp. nov., habitus. A. $\overbrace{}^{\Uparrow}$, holotype (MNHN). B. + , paratype (MNHN). Scale bars: $2.5 \mathrm{~mm}$. 
THORAX AND ABDOMEN. Pronotum narrower at base than base of elytra, 1.5 times as broad as long, broadest in middle, distinctly more convergent anteriad than posteriad; sides straight anteriad, but very weakly concave posteriad; anterior and posterior angles obtuse; anterior margin strongly concave, slightly bisinuate in middle; posterior margin strongly convex before scutellar shield; all sides of pronotum unbeaded. Pronotum not roughly rugo-punctate, with a narrow longitudinal medial callosity along its anterior half, covered by acicular to narrowly lanceolate scales being much smaller in size on sides than on disc, with setae along its anterior and lateral margins only. Propleura setose, with few small acicular scales along lateral margins only. Scutellar shield broadly rounded apically, not roughly rugo-punctate, covered with narrowly lanceolate scales becoming acicular and much denser along lateral margins. Elytra with three indistinct costae bearing scales; base of elytron with a swollen margin; humeral and apical umbones somewhat callose, glabrous; surface of elytra somewhat impressed behind humeral umbones.

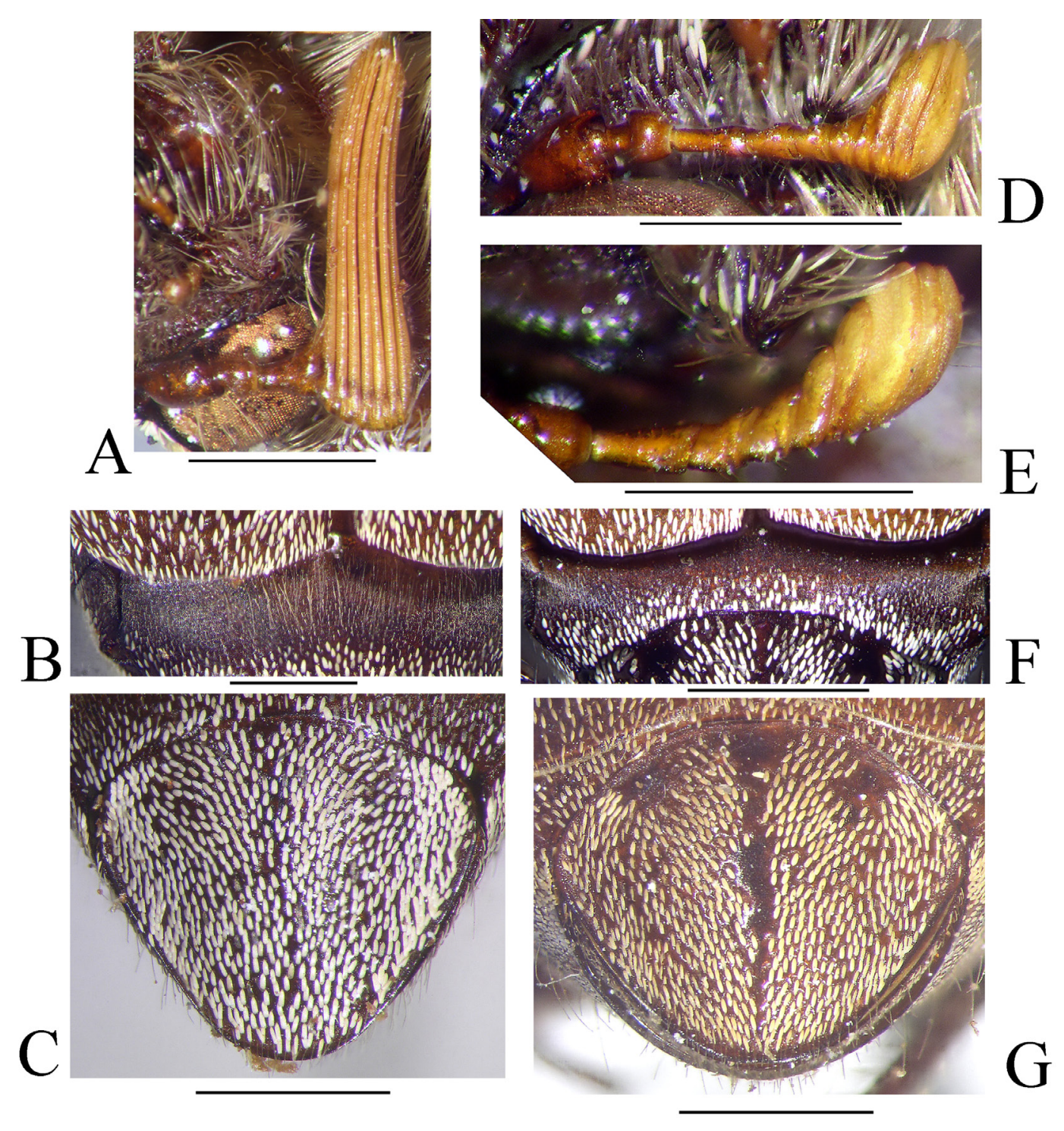

Fig. 4. Philacelota leucothea sp. nov., holotype, § (MNHN) (A-C) and paratype, G). A. Antenna, lateral view. B. Propygidium. C. Pygidium. D. Antenna, lateral view. E. Antenna, dorsolateral view showing relative size of club antennomeres. F. Propygidium. G. Pygidium. Scale bars: A, $\mathrm{C}-\mathrm{E}=1.5 \mathrm{~mm} ; \mathrm{B}=2 \mathrm{~mm} ; \mathrm{F}-\mathrm{G}=2.5 \mathrm{~mm}$. 
Interstices shallowly, unevenly and irregularly punctured; punctures somewhat rugose; scales small, rather evenly covering entire surface of elytra, lanceolate to narrowly lanceolate, becoming acicular close to margins. Propygidium (Fig. 4B) finely and densely punctured; its basal half covered with small acicular setae intermixed with sparse long setae along basal margin; setae replaced on distal half by small ovoid scales. Pygidium (Fig. 4C) fully covered by small ovoid scales, setose at apical margin only. Prosternum, mesoventrite and metaventrite densely and finely rugo-punctate, densely covered with long adpressed setae; metepimeron and metepisternum possessing scales; metaventrite lacking scales. First abdominal ventrite carinate in middle, covered with short, adpressed, hair-like setae replaced by densely setting, scale-like setae along posterior margin; $2^{\text {nd }}$ abdominal ventrite covered by small lanceolate scales intermixed with adpressed setae on its anterior half; remaining abdominal ventrites covered by small lanceolate and ovoid scales evenly distributed, but concentrated into dense patches on uppermost parts of ventrites; $3^{\text {rd }}$ to $5^{\text {th }}$ abdominal ventrites with few isolated long setae on lateral thirds only; last visible ventrite with several rows of moderately short, adpressed setae along its apical margin; sutures between $2^{\text {nd }}$ to $5^{\text {th }}$ abdominal ventrites obliterated in middle.

Legs. Protibiae unidentate, with spur short and thick; middle and hind tibiae gracile; apex of hind tibiae with 13 separated bristles. Femora setose and moderately densely covered with lanceolate scales; tibiae with sparse lanceolate scales and spiniform setae; tarsi with setae only. Tarsomeres 1-4 shortened, especially of the fore tarsi; $1^{\text {st }}$ tarsomere of hind tarsi only slightly longer than $2^{\text {nd }}$. Claws bifurcate, with lower lobe slightly closer to upper one than to base and almost parallel to upper one, distinctly shorter, but as broad as the latter.

Genitalia. Aedeagus (Fig. 5A-B) strongly arcuate; phallobase conspicuously humped dorsally at its distal extremity; parameres almost uniformly deep along their length in lateral view, with apical extensions large, boot-shaped.

VARIATION. Length $14.0 \mathrm{~mm}$, greatest width $5.5 \mathrm{~mm}$. Margins of clypeus less angular than in holotype. Fronto-clypeal suture somewhat carinate in middle. Scales on dorsal surface of head, pronotum and elytra smaller and sparser than in holotype. Elytra with four costae more pronounced than in holotype. Abdominal ventrites more setose than in holotype.
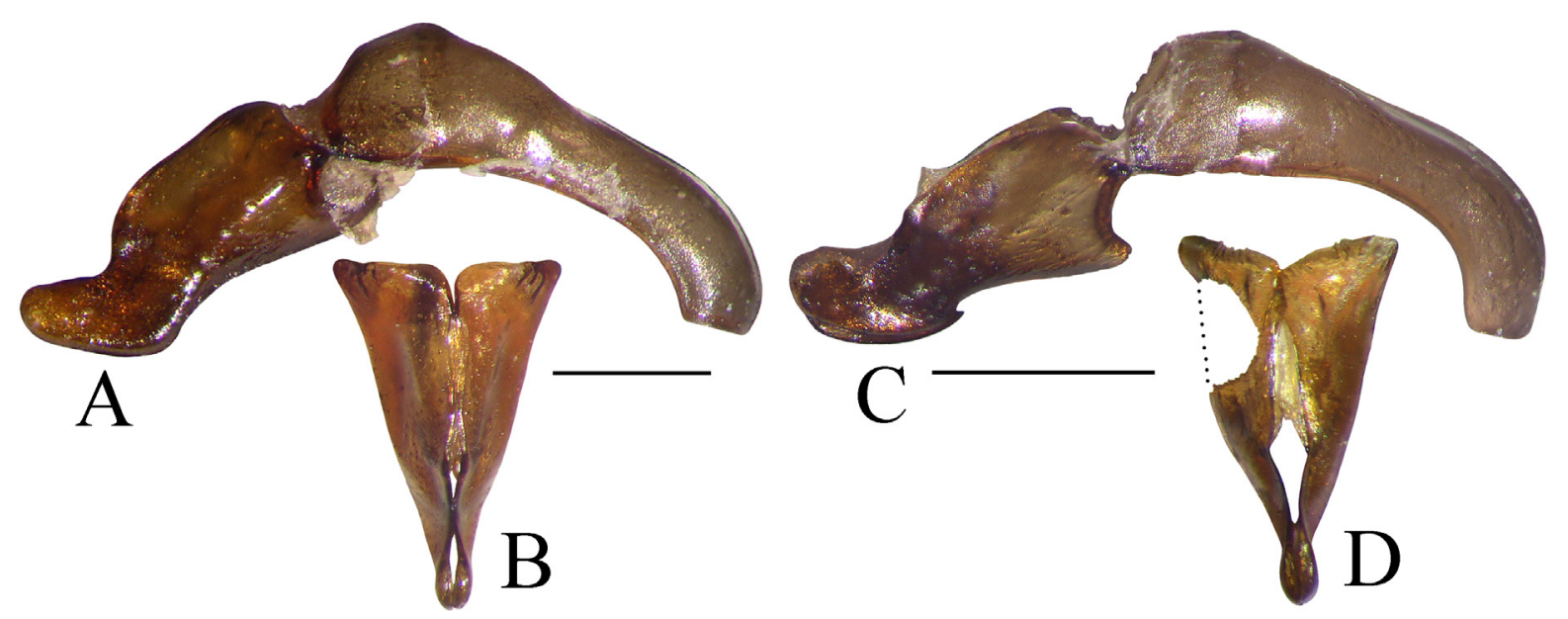

Fig. 5. A-B. Philacelota leucothea sp. nov., holotype, $ð$ (MNHN). A. Aedeagus, lateral view. B. Parameres, dorsal view. - C-D. P. submaculata Heller, 1900, from Kema, Sulawesi, §̊ (MNHN). C. Aedeagus, lateral view. D. Parameres, dorsal view. Scale bars: $A-B=1.5 \mathrm{~mm}$; $-\mathrm{D}=2 \mathrm{~mm}$. 


\section{Female}

Habitus: see Fig. 3B. Length 16.0-17.0 mm, greatest width 6.5-7.0 mm. Fronto-clypeal suture concave in middle. Antennal club (Fig. 4D-E) consists of five antennomeres: $2^{\text {nd }}$ antennomere $1.4-1.7$ times as long as $1^{\text {st }}\left(1^{\text {st }}\right.$ antennomere sometimes only slightly exceeding anteromedial process of last antennomere of funicle in length), $2^{\text {nd }}$ antennomere one-third to two-thirds as long as $3^{\text {rd }}, 3^{\text {rd }}$ antennomere equal to or slightly shorter than $4^{\text {th }} ; 4^{\text {th }}$ and $5^{\text {th }}$ antennomeres of equal length. Funicle: $4^{\text {th }}$ and $5^{\text {th }}$ antennomeres with conspicuous anteromedial process, $3^{\text {rd }}$ antennomere as long as $4^{\text {th }}$ and $5^{\text {th }}$ combined. Last maxillary palpomere more attenuated than in male. Scales on pronotum and especially on elytra unevenly distributed, intermixed with glabrous spaces forming a variegated pattern. Elytra with three-four more or less developed costae; humeral umbones conspicuously produced backward, with surface of elytra distinctly impressed behind them. Propygidium lacking long setae (Fig. 4F). Pygidium with glabrous medial stripe, sometimes callose on its basal half (Fig. 4G). Abdominal ventrites more inflated than in male. Protibial spur longer than in male. Apex of hind tibiae with 16 short, separated bristles. Tarsi shorter than in males; $1^{\text {st }}$ and $2^{\text {nd }}$ tarsomeres of hind tarsi equal in length.

\section{Differential diagnosis}

This new species is most similar to $P$. submaculata Heller, 1900 from northern Sulawesi in the possession of squamose vestiture (vs setose in P. jakli Zidek, 2018 and P. sulana Heller, 1900). Philacelota leucothea sp. nov. differs from $P$. submaculata in the following respects: long hair-like setae on the basal half of the propygidium very sparse in males and absent in females (vs dense in both sexes), much less callose pronotum and upper surface of the head, less costate elytra, and finer and sparser puncturation of their interstices. Furthermore, the males of $P$. leucothea sp. nov. differ from the males of $P$. submaculata in the elytra uniformly covered with scales (vs elytral costae glabrous), in the absence of the bare longitudinal stripe on the pygidium (vs present), and in the shape of the aedeagus (Fig. 5).

\section{Identification key for the species of Engertia and Philacelota}

1. Antennal club with 5-7 lamellae in males and 4 or 5 lamellae in females, those of males conspicuously elongated; scales on elytral interstices aggregated into spots or stripes

- Antennal club with 3-5 lamellae in both sexes (rarely more than 3); when more than 3 in number, club lamellae not conspicuously elongated in males, and scales of elytral interstices never aggregated into spots or stripes other Indo-Australian leucopholine genera

2. Antennal club of males with 7 lamellae; $3^{\text {rd }}$ antennomere elongated in both sexes (Fig. 6B-D) (Philacelota).....

- Antennal club of males with 5 or 6 lamellae; $3^{\text {rd }}$ antennomere short in both sexes (Fig. 6A-C) (Engertia)......

3. Body vestiture squamose; parameres compressed laterally, with irregular outlines ........................ 4

- Body vestiture setose; parameres tube-like with expanded tips (unknown in P. sulana) ................ 5

4. Upper surface of head and disc of pronotum with irregular callose areas of variable expression in both sexes. Males: basal half of propygidium with dense long setae; elytral costae glabrous; aedeagus as on Fig. 5C-D. Females: basal half of propygidium with long setae; puncturation of the elytral interstices dense and coarse (Indonesia: Sulawesi).

P. submaculata Heller, 1900

- Upper surface of head and disc of pronotum with longitudinal callose stripe in both sexes. Males: basal half of propygidium with minute acicular and sparse long setae; elytral costae scaled; aedeagus as on Fig. 5A-B. Females: basal half of propygidium with minute acicular setae; puncturation of the elytral interstices sparse and fine (Philippines: Luzon).

P. leucothea sp. nov. 
5. Protibiae unidentate in male; pronotum widest at base; setae of body vestiture very short and sparse (Indonesia: Sula Mangoli)

.P. sulana Heller, 1900

- Protibiae weakly bidentate in male; pronotum widest at midlength; setae of body vestiture long and dense (Indonesia: Flores).

P. jakli Zidek, 2018

6. Antennal club with conspicuously elongated antennomeres. Males (unknown for E. maculosa) .... 7

- Antennal club with short antennomeres. Females (unknown for E. allolepis sp. nov., E. germanica and E. papuana).

7. Antennal club with 6 lamellae (Philippines: Leyte, Palawan).

E. lii Keith, 2006

- Antennal club with 5 lamellae

8. Scales heterogeneous in shape in two outermost interstices and along apical margin of elytra. Aedeagus more arcuate in profile and more robust in shape (as on Fig. 2G) (Indonesia: Ambon).....

E. allolepis sp. nov.

- Scales homogeneous in shape in all interstices and along apical margin of elytra. Aedeagus less arcuate in profile (except E. germanica) and always more gracile in shape (as on Fig. 2J)............. 9

9. Elytra covered with ovoid to lanceolate scales; scales present on labrum and metaventrite........... 10

- Elytra covered with setiform scales; labrum and metaventrite with setae only...............................11

10. Elytra covered with ovoid scales; scales along midline of abdominal ventrites not aggregated into spots (Indonesia: islands of Ambon, Yapen and Miosidi)

E. amboinae (Brenske, 1897)

- Elytra covered with lanceolate scales; scales along midline of abdominal ventrites aggregated into small spots (New Guinea).

E. papuana (Moser, 1913)

11. Setiform scales on elytra thick; pygidium mainly setigerous; scales along midline of abdominal ventrites not aggregated into spots (Indonesia: islands of Seram, Ambon and Saparua).....

E. setifera (Moser, 1913)

- Setiform scales on elytra thin; pygidium mainly scaly; scales along midline of abdominal ventrites aggregated into spots (New Guinea).

E. germanica Prokofiev, 2016

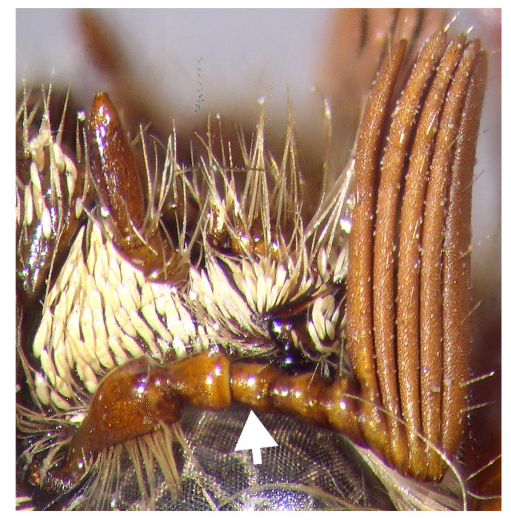

A

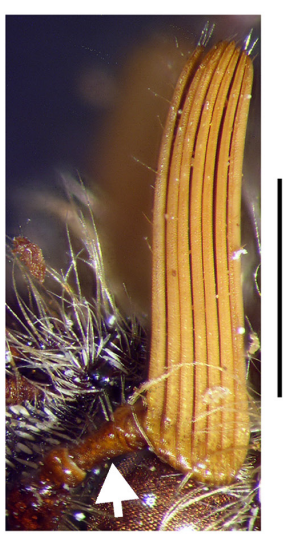

$\mathrm{B}$
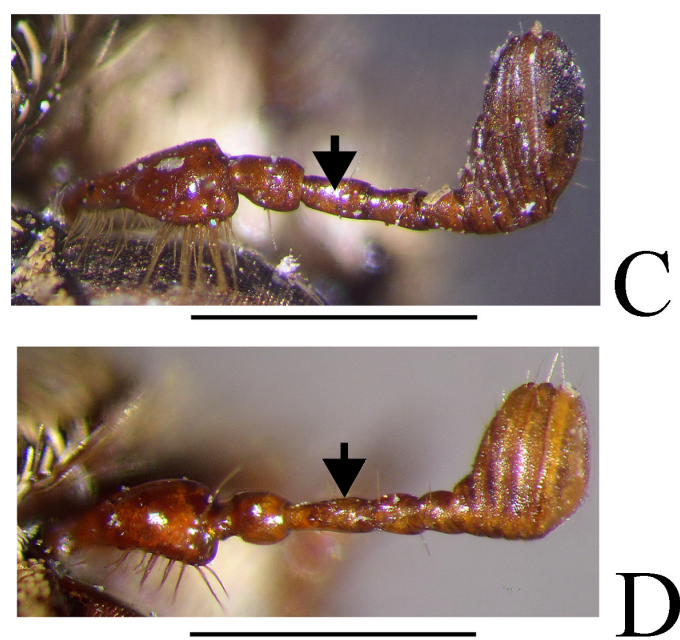

Fig. 6. Shape of $3^{\text {rd }}$ antennomere (arrowed) in males (A-B) and females $(C-D)$ of the type species of the genera Engertia Dalla Torre, 1913 and Philacelota Heller, 1900. A, C. Engertia amboinae (Brenske, 1897). B, D. Philacelota submaculata Heller, 1900. Scale bars $=1.5 \mathrm{~mm}$. 
12. Antennal club with 5 lamellae, first two abbreviated (Philippines: Leyte, Palawan)

E. lii Keith, 2006

- Antennal club with 4 lamellae, only first one abbreviated

13. Scales on elytra aggregated into spots; clypeus semicircular (Sri Lanka).

E. maculosa (Brenske, 1896)

- Scales on elytra aggregated into longitudinal stripes; clypeus polygonal

14. Scales on elytra ovoid (Indonesia: islands of Ambon, Yapen and Miosidi)

E. amboinae (Brenske, 1897)

- Scales on elytra setiform (Indonesia: islands of Seram, Ambon and Saparua)

E. setifera (Moser, 1913)

\section{Discussion}

The genus Engertia currently comprises seven species distributed in Sri Lanka and the Indo-Australian islands of Philippines, the Moluccas and New Guinea, including small islands in Cenderawasih Bay. The genus Philacelota includes four species known from the Philippines and Indonesia (islands of Luzon, Sulawesi, Sula and Flores). The two genera are very similar to one another and the recently described E. lii fills the gap between of Engertia and Philacelota in the number of club antennomeres. Moreover, the aedeagus of $E$. lii is more similar to that of $P$. submaculata than of E. amboinae in having laterally compressed parameres with irregular outlines, triangular in dorsal view (Keith 2006: figs 9-10), while the parameres of $P$. jakli are elongated (tube-like) with expanded tips like in most species of Engertia (Zidek 2018: figs 4-5). Nevertheless, Engertia is retained here as a genus distinct from Philacelota on the basis of the constant differences between the members of these genera in the length of the $3^{\text {rd }}$ antennomere in both sexes (Fig. 6). The relationships between Engertia and Philacelota and the other leucopholine genera remain unclear at the present state of knowledge.

\section{Acknowledgements}

I am indebted to all curators of the studied collections for their fruitful assistance, to Aleš Bezděk, Maxwell Barclay, Matthias Seidel and to an anonymous reviewer for improving the manuscript, and to Christopher Scharpf for linguistic correction of the Introduction and Discussion sections.

\section{References}

Brenske E. 1896. Neue Melolonthiden aus Africa und Asien. Stettiner entomologische Zeitschrift 57: 178-205.

Brenske E. 1897. Neue Gattungen und Arten der Melolonthiden aus Afrika und Asien. Stettiner entomologische Zeitung 58: 96-120.

Heller K.M. 1900. Neue Käfer von Celebes IV. Abhandlungen und Berichte des königlichen zoologischen und anthropologisch-ethnographischen Museums zu Dresden 9: 1-46. Available from https://biodiversitylibrary.org/page/46189178 [accessed 10 Sep. 2019].

Keith D. 2006. Reflexions sur le genre Engertia et description d'une nouvelle espèce des Philippines. Lambillionea 106: 90-94.

Moser J. 1913. Beitrag zur Kenntnis der Melolonthiden I. Deutsche entomologische Zeitschrift 3: 271297. Available from https://archive.org/details/biostor-101429 [accessed 10 Sep. 2019].

Prokofiev A.M. 2015. A male of Engertia setifera (Coleoptera: Scarabaeidae: Melolonthinae) from Seram Island, Indonesia. Baltic Journal of Coleopterology 15: 25-28. 
Prokofiev A.M. 2016a. New genera and species of the Papuan Leucopholini and Melolonthini (Coleoptera, Scarabaeidae: Melolonthinae). Euroasian Entomological Journal 15: 68-74. [In Russian.]

Prokofiev A.M. 2016b. On the phytophagous scarabs of the subfamilies Dynastinae, Rutelinae, and Melolonthinae from the Schouten Islands (= Kepulauan Biak), Indonesian Papua (Coleoptera: Scarabaeidae). Species Diversity 21: 71-77. https://doi.org/10.12782/sd.21.1.071

Zidek J. 2018. A new species of Philacelota Heller (Scarabaeidae: Melolonthinae: Melolonthini) from Flores Island, Indonesia. Insecta Mundi 0679: 1-6.

Available from http://digitalcommons.unl.edu/insectamundi/1176 [accessed 19 Sep. 2019].

Manuscript received: 6 June 2018

Manuscript accepted: 21 August 2019

Published on: 3 October 2019

Topic editor: Gavin Broad

Section editor: Max Barclay

Desk editor: Kristiaan Hoedemakers

Printed versions of all papers are also deposited in the libraries of the institutes that are members of the EJT consortium: Muséum national d'Histoire naturelle, Paris, France; Meise Botanic Garden, Belgium; Royal Museum for Central Africa, Tervuren, Belgium; Royal Belgian Institute of Natural Sciences, Brussels, Belgium; Natural History Museum of Denmark, Copenhagen, Denmark; Naturalis Biodiversity Center, Leiden, the Netherlands; Museo Nacional de Ciencias Naturales-CSIC, Madrid, Spain; Real Jardín Botánico de Madrid CSIC, Spain; Zoological Research Museum Alexander Koenig, Bonn, Germany; National Museum, Prague, Czech Republic. 